Yilmaz, G., Akcamete-Gungor, A. and Demirors, O. (2017). “A review on capability and maturity models of building information modelling." In: LC3 2017: Volume I - Proceedings of the Joint Conference on Computing in Construction (JC3), July 4-7, 2017, Heraklion, Greece, pp. 627-636. https://doi.org/10.24928/JC3-2017/0309.

\title{
A REVIEW ON CAPABILITY AND MATURITY MODELS OF BUILDING INFORMATION MODELLING
}

\author{
Gokcen Yilmaz ${ }^{1}$, Asli Akcamete-Gungor ${ }^{2}$, and Onur Demirors ${ }^{3}$
}

\begin{abstract}
Process assessment and maturity models in software engineering are widely used for process improvement. Likewise, assessing BIM capability and maturity have important effects on increasing BIM performance and enhancing benefits of BIM usage. Thus, there are various BIM capability and maturity models in the literature which are important for users to be able to select appropriate model for their BIM assessment purposes. This study aims to identify and analyse BIM capability and maturity models in the construction industry by doing a systematic literature review. As a result of this review, a total of 189 articles are investigated and 84 of them are found to be relevant. The identified methods are compared based on their purposes and components and the findings are presented in a comparison table. Additionally, widely used capability and maturity models in software engineering are identified and these models are compared with BIM capability and maturity models in terms of their structures. This comparison will be utilized for development of a process based BIM capability assessment model.
\end{abstract}

Keywords: Capability maturity model, building information modelling, process assessment, construction.

\section{INTRODUCTION}

Building information modelling (BIM) have a significant impact on the efficiency of generation of building information and sharing of this information among various stakeholders throughout the building lifecycle. There is a big shift towards the adoption of BIM. According to a recent National BIM report, which highlights the BIM adoption and usage rates within the UK, $54 \%$ of the respondents such as Architects, Project Managers, and BIM Managers are aware of and actively using BIM, $42 \%$ are aware of BIM and only $4 \%$ are unaware of BIM (Waterhouse and Philp 2016). This is a result of the measures taken by the UK government, mandating the UK construction industry to be at Level 2 BIM maturity by 2016 (Cabinet Office 2011).

Since awareness and diffusion of BIM is increasing in various parts of the world similar to UK, many international construction companies are willing to transform their traditional approach into BIM integrated project delivery methods. However, adoption of BIM requires several changes in the organizations, such as aligning business processes to BIM and enabling BIM savvy work force. According to Eadie et al. (2014), top three barriers for adopting BIM are lack of information about return on investment, lack of flexibility for cultural change, and cost of training.

PhD student, Research Assistant, Informatics Institute, Middle East Technical University, Ankara, Turkey,ygokcen@metu.edu.tr

2 Assistant Professor, Department of Civil Engineering, Middle East Technical University, Ankara, Turkey, akcamete@metu.edu.tr

3 Professor, Informatics Institute, Middle East Technical University, Ankara, Turkey, demirors@metu.edu.tr 
Even after the adoption of BIM, the organizations need to gauge the effectiveness of their BIM methodology. Awareness of capability and maturity level gives organizations various opportunities such as enhancing existing BIM deliverables and improving business processes. Therefore, several capability and maturity models are created in order to measure level of BIM capability and maturity. Although there are a number of comparative studies on these models, a comprehensive literature review has not been done in recent years. Moreover, there is not enough emphasis in existing studies on when and how the models can be used.

In this study, we have identified and compared BIM capability and maturity models through a systematic literature review. Organizations that would like to assess their BIM maturity and process capabilities, may choose the most relevant models according to this baseline. This study would also be utilized as an initial step for developing a BIM capability assessment model.

In this paper; the methodology of systematic literature review is explained in Section 2 , findings and results are presented in Section 3, and lastly, conclusion and discussion is given in Section 4.

\section{METHODOLOGY}

In this study a systematic literature review is conducted for identifying models in construction industry which are developed to assess BIM capability and maturity. This systematic literature review consists of two lookups; search in databases and manual search. A total number of 189 papers are investigated, 84 of which are found relevant. Out of these 84 papers, 11 of them found in Scopus, 16 in Web of Science, and 57 are found through manual search.

Capability and maturity models used in software engineering are also included within the context. However, an exhaustive literature review in software engineering is not required because the focus of this paper is mainly civil engineering. Thus, the most commonly used capability and maturity models in software engineering are selected and explained in detail in Section 3.

\subsection{Search in Databases}

Scopus and Web of Science are preferred to conduct the systematic literature review since these are comprehensive and commonly used databases in systematic literature review articles. Most relevant journals, which are given in Table 2, are identified and search queries are refined by these journals to limit the findings. Resulting articles found in Scopus, are not compared with the resulting articles found in Web of Science. Therefore, overlapping articles are not eliminated. For each database, queries used, hits, and number of relevant articles are given in Table 1.

Table 1: Query and results for search in databases

\begin{tabular}{llll}
\hline \multicolumn{1}{c}{ Query } & \multicolumn{1}{c}{ Database } & Hits & Relevant \\
\hline $\begin{array}{l}\text { TITLE-ABS-KEY (construction OR bim AND } \\
\text { capability AND maturity AND assessment) }\end{array}$ & Scopus & 16 & 11 \\
TS= (construction OR BIM) AND TS=maturity & Web of Science & 33 & 16 \\
\hline
\end{tabular}




\subsection{Manual Search}

In order to perform a comprehensive systematic literature review, a manual search is also conducted by using the identified journals from the database searches. For this purpose, web sites of each journal are visited to identify the related articles. For the search criteria, the key words "bim", "construction" and "maturity" are used. By using the specified search criteria, related articles are identified and collected in a list. Overlapping articles that are already found in databases are excluded from the manual search. Articles are removed from the list in two step. For the first elimination, articles are reviewed by simply looking at their titles. For the second elimination, articles which passed the first elimination are further examined by looking at their abstracts and then the irrelevant articles are eliminated (see Table 2). The remaining articles are read in detail and the ones containing BIM capability and maturity methods are included in the scope of this study.

Table 2. Search criteria and number of articles found in manual search

\begin{tabular}{|c|c|c|c|}
\hline Journals & Search criteria & $\begin{array}{c}\text { No in } \\
\text { 1st } \\
\text { elim. }\end{array}$ & $\begin{array}{l}\text { No in } \\
\text { 2nd } \\
\text { elim. }\end{array}$ \\
\hline Advanced Engineering Informatics & bim AND maturity & 4 & 1 \\
\hline Advanced Materials Research & $\begin{array}{l}\text { bim OR (construction AND } \\
\text { maturity) }\end{array}$ & 12 & 2 \\
\hline Architectural Engineering and Design Mang. & bim AND maturity & 15 & 7 \\
\hline Automation in Construction & bim OR maturity & 21 & 11 \\
\hline Building Research and Information & bim AND maturity & 8 & 1 \\
\hline Business Process Management Journal & bim OR maturity & 0 & 0 \\
\hline Canadian Journal of Civil Engineering & bim OR maturity & 3 & 3 \\
\hline $\begin{array}{l}\text { Communications in Computer and Information } \\
\text { Science }\end{array}$ & bim & 1 & 1 \\
\hline $\begin{array}{l}\text { Communications of the Association for Information } \\
\text { Systems }\end{array}$ & $\begin{array}{l}\text { (construction AND bim) } \\
\text { OR maturity }\end{array}$ & 4 & 2 \\
\hline Computer aided Civil and Infrastructure Eng. & bim & 1 & 0 \\
\hline Computer-aided Design & maturity & 1 & 0 \\
\hline Computing in Civil Engineering & bim and maturity & 1 & 1 \\
\hline Construction Innovation & $\begin{array}{l}\text { bim OR (construction and } \\
\text { maturity) }\end{array}$ & 22 & 12 \\
\hline Construction Management and Economics & bim and maturity & 14 & 2 \\
\hline Expert Systems with Applications & bim & 1 & 0 \\
\hline Information Management and Computer Security & NA & 0 & 0 \\
\hline International Journal of E-collaboration & NA & 0 & 0 \\
\hline Int. J. of Productivity and Performance Mang. & bim & 1 & 0 \\
\hline J. of Civil Engineering and Management & $\begin{array}{l}\text { bim AND construction } \\
\text { AND maturity }\end{array}$ & 1 & 0 \\
\hline J. of Computing and Information Technology & construction & 1 & 0 \\
\hline J. of Construction Engineering and Management & bim & 18 & 9 \\
\hline J. of Engineering and Architecture & bim & 1 & 1 \\
\hline J. of Management in Engineering & bim & 10 & 4 \\
\hline $\begin{array}{l}\text { Ontologies for Software Engineering and Software } \\
\text { Technology }\end{array}$ & NA & 0 & 0 \\
\hline
\end{tabular}


In Table 2, the keywords which are used for searching each journal is presented along with the number of relevant articles found after the first and second eliminations. As a result, a total of 57 articles identified as including content relevant to capability and maturity assessments for BIM.

\section{FINDINGS AND RESULTS}

We have started with describing the capability and maturity models in software engineering first, since these models are widely accepted and have many citations from various domains. Then, through a systematic review, 84 relevant articles for BIM capability and maturity models are identified in construction industry. After examining these articles in detail, seven capability and maturity models were determined. Commonly used five models in software engineering and seven models in construction industry are explained in Section 3.1 and Section 3.2, respectively.

\subsection{Capability and Maturity Assessment in Software Engineering}

The recent ISO/IEC 33000 series of standard replaces the 15504 (ISO/IEC 2000) (ISO/IEC 2012a) (ISO/IEC 2012b) (ISO/IEC 2004) (ISO/IEC 2006) which provides guidance on how to utilize process assessment for conducting process improvement.

ISO/IEC 33000 includes a process reference model and the core of the model is composed of two key elements: process assessment model and measurement method. The standard is composed of eleven parts. First part explains the concepts of process assessment and includes a glossary for assessment terms (ISO/IEC 2015a). Process reference model helps to define scope of the assessment and definitions of inter-related processes. It has two components, which are domain and scope, and process purpose and process outcomes. ISO/IEC 12207 standard is used for defining purposes and outcomes (ISO/IEC, 2008). Measurement method is a schema that is used for rating capability of processes. Capability levels, process attributes, and rating scale are defined within the measurement method. There are six capability levels as; L0-incomplete, L1-performed, L2managed, L3-established, L4-predictable, and L5-optimizing and nine process attributes as; process performance, performance measurement and work product management, process definition and process deployment, process control, process innovation, process measurement, and process optimization. Those process attributes are rated by using the performance indicators defined in the model. In order to depict the results, ordinal scale is used. Those values are; not achieved, partially achieved, largely achieved, and fully achieved for 0 to $15 \%, 15 \%$ to $50 \%, 50 \%$ to $85 \%, 85 \%$ to $100 \%$ achievement rates, respectively. Process assessment is composed of five steps including planning, data collection, data validation, process attribute rating, and reporting (ISO/IEC 2015b) (ISO/IEC 2015c) (ISO/IEC 2015d). It also provides guidance for process improvement and capability determination by defining the strengths, weaknesses, and process-related risks. Process improvement has eight steps; examining organization's business goals, initiating process improvement cycle, assessing current capability, developing action plan, implementing improvements, confirming improvements, sustaining improvements, and monitoring performance (ISO/IEC 2015e).

CMMI, is first created by the CMU Software Engineering Institute and later is owned and managed by CMMI Institute. CMMI addresses three areas of interest: CMMI for Development, CMMI for Services, and CMMI for Acquisition.

CMMI for Development, which is the most relevant one for construction projects, is a guideline for applying best practices to improve processes of development organizations. 
It defines key process areas such as requirements development, validation and verification. It includes 22 key process areas and for each process area the model contains components such as purpose statement, generic goals, specific goals, generic practices and specific practices. CMMI supports two improvement approaches namely continuous representation and staged representation. Continuous representation focuses on specific processes and used to state the capability level of the specific processes. Four capability levels, which are L0-incomplete, L1-performed, L2-managed, L3-defined, are used for process improvement in individual process areas. Staged representation is used to state the maturity of the organization. Five maturity levels, which are L1-Initial, L2-managed, L3quantitatively managed, L5-optimizing, are used to achieve process improvement across multiple process area (SEI 2010).

Standard CMMI Appraisal Method for Process Improvement (SCAMPI) is a guideline for identifying strengths, weaknesses, and ratings relative to appraisal reference model which is CMMI. SCAMPI is composed of three phases: plan and prepare for appraisal, conduct appraisal and report result. It provides integrated appraisal method for internal process improvement, supplier selection, and process monitoring (SCAMPI Upgrade Team 2011).

Lastly, ITIL is a user guide which allows organizations to measure the maturity of their service management processes. It describes five levels of maturity as L1-initial, L2repeatable, L3-defined, L4-managed. Five service processes are defined as service strategy, service, design, service transition, service operation, and continual service improvement (Rudd and Sansbury 2013).

The key elements of the capability and maturity models used in software engineering can be clustered under three parts: [a] process reference model, [b] process measurement framework, and [c] process improvement method. While, process reference model identifies key processes and defines their purpose and outcomes, process measurement framework includes the details about process attributes, quality levels and rating scale for process assessment. Strategies for process improvement is derived based on the process assessment reports. In Table 3, the capability and maturity models are compared in terms of their content, contained parts, maturity levels, and assessment styles.

Table 3: Comparison of process assessment and maturity models

\begin{tabular}{|c|c|c|c|c|}
\hline Name & Content & $\begin{array}{c}\text { Parts } \\
\text { contained }\end{array}$ & $\begin{array}{l}\text { No of } \\
\text { mat. } \\
\text { levels }\end{array}$ & $\begin{array}{c}\text { Assmnt. } \\
\text { style }\end{array}$ \\
\hline ISO/IEC 12207 & Defines software lifecycle processes & [a] & NA & NA \\
\hline $\begin{array}{l}\text { ISO/IEC } 33000 \\
\text { (11 Parts) } \\
\text { CMMI for } \\
\text { (Development) }\end{array}$ & $\begin{array}{l}\text { Provides a guideline for software process } \\
\text { assessment and process improvement } \\
\text { Defines best practices to provide a } \\
\text { guideline for process improvement }\end{array}$ & $\begin{array}{l}{[\mathrm{a}],[\mathrm{b}],[\mathrm{c}]} \\
{[\mathrm{a}],[\mathrm{b}]}\end{array}$ & $\begin{array}{l}6 \text { levels } \\
(0-5) \\
5 \text { levels } \\
(1-5)\end{array}$ & $\begin{array}{l}\text { Self and } \\
\text { outside } \\
\text { NA }\end{array}$ \\
\hline SCAMPI & $\begin{array}{l}\text { Defines how to conduct appraisal based } \\
\text { on CMMI to create process improvement } \\
\text { action plan }\end{array}$ & {$[\mathrm{b}],[\mathrm{c}]$} & NA & $\begin{array}{l}\text { Self and } \\
\text { outside }\end{array}$ \\
\hline ITIL & $\begin{array}{l}\text { Defines how to measure maturity of the } \\
\text { service management processes }\end{array}$ & {$[\mathrm{a}],[\mathrm{b}]$} & $\begin{array}{l}5 \text { levels } \\
(1-5)\end{array}$ & Self \\
\hline
\end{tabular}

Required parts for a capability and maturity model are; [a] process reference model, [b] process measurement framework, and [c] process improvement method. 


\subsection{Capability and Maturity Assessment in Construction Industry}

One of the most cited BIM maturity model is BIM Maturity Matrix, which is a knowledge tool for evaluating performance of BIM, organizations, and projects. It helps organizations to assess their current performance and allows improvement. Matrix is composed of three components which are competency areas, capability stage, and organizational scale. Competency sets are defined as policy, process and technology and each set has competency areas which are given as (Succar 2010): Policy - Regulatory, contractual, preparatory; Process - Infrastructure, products, human resource and leadership; Technology - Software, hardware and network. BIM capability stages contains three values which are object based modelling, model based collaboration, and network based integration. Organizations has three scales: macro, meso, and micro. BIM capability stage and the scale of the organization take one specific value. Competency areas, BIM capability stage and organizational scale are rated against 5 maturity levels. Each level is given a constant maturity point as Level a, b, c, d, and e for 10, 20, 30, 40 and 50 points, respectively. As there are twelve individual points (ten competency areas, one capability stage and one organizational scale), the maturity discovery score is the average of total points divided by twelve (Succar 2010) (see Table 4).

National BIM Standard (NBIMS) defined a BIM CMM to be used as a guideline to determine the maturity level of BIM. There are two versions of BIM CMM which are tabular BIM and interactive BIM. The Tabular CMM is in matrix format with 11 areas of interest assessed against 10 maturity levels. Interactive CMM has the same information as the tabular form, but it is in excel format. In version three of the National BIM Standard, concept of Minimum BIM is defined. Minimum BIM is a minimum total points for maturity against 11 areas of interests which are required to contain the 11 areas: richness, life-cycle view, change management, roles or discipline, business process, timeliness and response, delivery method, graphical information, spatial capability, information accuracy, and interoperability and industry foundation class support. In order to improve BIM maturity, steps to be followed are summarized in the standard (National Institute of Building Sciences buildingSMART alliance 2015).

Virtual Design and Construction (VDC) Scorecard is developed by Stanford University and measures the project performance against an industry benchmark. It includes four major areas, which are planning, adoption, technology and performance. These areas are divided into ten divisions and each division is evaluated by 56 metrics. Area scores are calculated by weighted sum of division scores, and overall VDC score is calculated by weighted sum of area scores. VDC score is based on percentage scale and reflects the project performance relative to a benchmark which consists of 150 pilot projects' VDC scores (Kam et al. 2013).

The SPICE FM framework, which is developed by University of Salford, specifically focuses on Facility Management (FM) for improving FM processes (Amaratunga et al. 2002). SPICE FM defines 5 maturity levels which are L1-initial, L2-planned and tracked, L3-well defined, L4-quantitatively controlled, L5-continuously improving and key processes are defined at each level (Amaratunga et al. 2002) (Sarshar et al. 2004). Maturity level of an FM organization is decided based on the existence of the key processes. After maturity level and key processes of the organization are determined, key processes are assessed against process enablers which are commitment, ability, verification, evaluation, and activities (Amaratunga et al. 2002). Weaknesses and strengths of key processes are identified to derive improvement suggestions. To create continuous improvement, 
framework has three stages which are determining strategic targets, assessing existing FM management procedures, and implementing and monitoring (University of Salford 2001).

Table 4: Comparison of BIM capability and maturity models

\begin{tabular}{|c|c|c|c|c|c|}
\hline & Purpose & $\begin{array}{l}\text { Maturity } \\
\text { Levels }\end{array}$ & Metrics used & $\begin{array}{l}\text { Overall } \\
\text { score }\end{array}$ & $\begin{array}{c}\text { Rating } \\
\text { scale }\end{array}$ \\
\hline $\begin{array}{l}\text { BIM Maturity } \\
\text { Matrix }\end{array}$ & $\begin{array}{l}\text { Rates BIM, project } \\
\text { and organization } \\
\text { performances }\end{array}$ & $\begin{array}{l}\text { Initial } \\
\text { Defined } \\
\text { Managed } \\
\text { Integrated } \\
\text { Optimized }\end{array}$ & $\begin{array}{l}10 \text { areas, } 1 \\
\text { capability stage } \\
\text { and } 1 \text { org. scale }\end{array}$ & $\begin{array}{l}\text { Total points } \\
\text { subdivided } \\
\text { by } 12\end{array}$ & Ordinal \\
\hline $\begin{array}{l}\text { NBIMS BIM } \\
\text { CMM }\end{array}$ & $\begin{array}{l}\text { Rates maturity of } \\
\text { BIM }\end{array}$ & $\begin{array}{l}\text { Not certified } \\
\text { Min. BIM } \\
\text { Certified } \\
\text { Silver } \\
\text { Gold } \\
\text { Platinum }\end{array}$ & $\begin{array}{l}11 \text { areas of } \\
\text { interests } \\
\text { measured } \\
\text { against } 10 \text { levels } \\
\text { of maturity }\end{array}$ & $\begin{array}{l}\text { Sum of } 11 \\
\text { areas of } \\
\text { interests' } \\
\text { scores }\end{array}$ & Ordinal \\
\hline $\begin{array}{l}\text { VDC } \\
\text { Scorecard }\end{array}$ & $\begin{array}{l}\text { Rates project } \\
\text { performance relative } \\
\text { to industry } \\
\text { benchmark }\end{array}$ & $\begin{array}{l}\text { Conventional } \\
\text { Typical } \\
\text { Advanced } \\
\text { Best } \\
\text { Innovative }\end{array}$ & $\begin{array}{l}4 \text { key areas and } \\
10 \text { divisions and } \\
\text { a number of } \\
\text { individual } \\
\text { measures }\end{array}$ & $\begin{array}{l}\text { Weighted } \\
\text { sum of } 4 \\
\text { key areas' } \\
\text { scores }\end{array}$ & Ratio \\
\hline SPICE FM & $\begin{array}{l}\text { Determines maturity } \\
\text { of FM organizations } \\
\text { independent from } \\
\text { BIM }\end{array}$ & $\begin{array}{l}\text { Initial } \\
\text { Planned and } \\
\text { tracked } \\
\text { Well defined } \\
\text { Quantitatively } \\
\text { controlled } \\
\text { Continuously } \\
\text { improving }\end{array}$ & $\begin{array}{l}\text { Key processes } \\
\text { assessed against } \\
5 \text { process } \\
\text { enablers }\end{array}$ & $\begin{array}{l}\text { No scoring } \\
\text { system. } \\
\text { Weakness } \\
\text { and } \\
\text { strengths of } \\
\text { key } \\
\text { processes }\end{array}$ & $\begin{array}{l}\text { Based on } \\
\text { the } \\
\text { existence } \\
\text { of key } \\
\text { processes } \\
\text { at each } \\
\text { level }\end{array}$ \\
\hline $\begin{array}{l}\text { Facility } \\
\text { Owner's } \\
\text { Guide }\end{array}$ & $\begin{array}{l}\text { Measures the } \\
\text { maturity of BIM } \\
\text { planning elements }\end{array}$ & $\begin{array}{l}\text { Non-Existent } \\
\text { Initial } \\
\text { Managed } \\
\text { Defined } \\
\text { Quantitatively } \\
\text { managed } \\
\text { Optimizing }\end{array}$ & $\begin{array}{l}6 \text { main planning } \\
\text { elements and } 18 \\
\text { sub elements } \\
\text { are assessed } \\
\text { against } 6 \\
\text { maturity levels }\end{array}$ & $\begin{array}{l}\text { Total score } \\
\text { subdivided } \\
\text { by } 18\end{array}$ & Ordinal \\
\hline $\begin{array}{l}\text { BIM } \\
\text { Proficiency } \\
\text { Matrix }\end{array}$ & $\begin{array}{l}\text { Evaluates BIM } \\
\text { services performance }\end{array}$ & $\begin{array}{l}\text { Working } \\
\text { towards BIM } \\
\text { Certified BIM } \\
\text { Silver } \\
\text { Gold } \\
\text { Ideal }\end{array}$ & $\begin{array}{l}8 \text { areas of } \\
\text { interests assed } \\
\text { against } 4 \text { level } \\
\text { of maturity }\end{array}$ & $\begin{array}{l}\text { All areas of } \\
\text { interests' } \\
\text { scores } \\
\text { summation }\end{array}$ & Ordinal \\
\hline $\begin{array}{l}\text { Multi- } \\
\text { functional } \\
\text { BIM Maturity } \\
\text { Model }\end{array}$ & $\begin{array}{l}\text { Evaluates BIM } \\
\text { maturity in projects, } \\
\text { companies with a } \\
\text { portfolio of projects, } \\
\text { and the industry as a } \\
\text { whole }\end{array}$ & $\begin{array}{l}\text { Stage } 0 \\
\text { Stage } 1 \\
\text { Stage } 2 \\
\text { Stage } 3\end{array}$ & $\begin{array}{l}3 \text { domains and } \\
21 \text { subdomains. } \\
21 \text { subdomains } \\
\text { are assessed } \\
\text { against } 4 \text { levels } \\
\text { of maturity }\end{array}$ & $\begin{array}{l}\text { All } \\
\text { subdomains } \\
\text { are } \\
\text { weighted } \\
\text { equally }\end{array}$ & Ordinal \\
\hline
\end{tabular}


BIM Proficiency Matrix, which is designed by Indiana University, is used to assess BIM services performance in terms of eight areas: physical accuracy of the model, the presence of an integrated project delivery methodology, calculation mentality, location awareness, content creation, construction data, as-built modelling, and FM data richness. Those 8 categories are assessed against 4 level of maturity and summed up to calculate the score of each category. BIM maturity score is the sum of scores of all categories. This score helps to identify the maturity level of the BIM services. Matrix defines 5 levels of BIM maturity (Indiana University 2009).

Facility Owner's Guide developed by Penn State University helps facility managers to evaluate the organization's maturity of the BIM planning elements. Those elements are defined as BIM strategy, BIM uses, information, personnel, infrastructure, and process. Each planning element has sub elements with 18 of them in total. For instance; sub elements of BIM strategy are organizational mission and goals, BIM vision and objectives, management support, BIM champion, and planning committee. It defines 6 maturity levels and each sub element is assessed against maturity levels. If a sub element such as management support is at level 3, its score becomes 3. Overall maturity level is equal to weighted sum of all sub elements' scores (Messner et al. 2013).

A recent research is conducted to develop a multifunctional BIM Maturity Model. This model contains 3 domains which are technology, process, and protocol. Technology is composed of 7 subdomains: information accuracy, model data, quality assurance \& control, data security \& saving, technology infrastructure \& needs, BIM elements, and spatial \& coordination. Process domain contains 7 subdomains: clash analysis process, data exchange, CAD/BIM workflow, cross-disciplinary model coordination, delivery method, BIM project objective, and management support. Protocol domain contains 7 subdomains: interoperability/IFC support, project deliverables, doc \& modelling standards, standard operating process, role \& responsibility, compensation expectations, and BIM \& facility data requirements. Model defines 4 levels of maturity. Subdomains are assessed against maturity levels and they are weighted equally to calculate the overall maturity score (Liang et al. 2016).

In Table 4, the models described above are compared in terms of their usage purpose and the components of the process assessment method (maturity levels, metrics used, overall score, and rating scale).

\section{CONCLUSIONS AND DISCUSSION}

The relevant articles (84), which are found by the systematic literature review, are studied and seven capability and maturity models are identified for construction industry. Each capability and maturity model has different focus area. Three of these models focus on assessing capability and maturity of construction projects, and one of them is for evaluating the building information model in terms of the information contained in. Moreover, each model defines various maturity levels and metrics in their context. Therefore, users should choose the appropriate model according to their capability and maturity assessment purposes.

The well accepted five capability and maturity methods in software engineering are analyzed in detail by summarizing the included parts, maturity levels and assessment styles. There are three key components in all of the five methods. These are; process reference model, process measurement framework and process improvement method. In order to conduct a complete process assessment, all of these components are required. In the models for construction industry, only SPICE FM have a process reference model 
component which the process assessment is based on. However, the SPICE FM defines processes in facility management phase only and these processes are not related to BIM.

In conclusion, capability and maturity models in construction industry do not contain a similar structure to models in software engineering. A structured BIM capability and maturity model including a process reference model and a measurement framework, have a potential to enable benchmarking, systematic appraisal, and comparing project performances within the organization in the construction industry. As a further study, we will identify processes based on the construction project life cycle and create a process reference model. Later, a measurement framework for assessing BIM capability and maturity, will be developed in order to conduct assessments in a structured way.

\section{REFERENCES}

Amaratunga, D., Sarshar, M. and Baldry, D. (2002). Process Improvement in facilities management: the SPICE approach. Business Process Management Journal, 8(4), 318337. http://doi.org/10.1108/14637150210434982

Cabinet Office, H. (2011). Government Construction Strategy. Construction, 96(May)

ISO/IEC. (2000). The ISO/IEC 15504 - 1 Information technology - Process assessment Part 1: Concepts and Vocabulary.

ISO/IEC. (2004). ISO/IEC 15504-4 Information technology - Process assessment - Part 4: Guidance on use for process capability determination. Software Process: Improvement and Practice.

ISO/IEC. (2006). The ISO/IEC 15504 - 5 Information technology - Process assessment Part5: An exemplar Process Assessment Model.

ISO/IEC. (2008). The ISO/IEC 12207 Systems and software engineering-Software life cycle processes. ISO Standard.

ISO/IEC. (2012a). The ISO/IEC 15504 - 2 Information technology - Process assessment Part 2: Performing an assessment.

ISO/IEC. (2012b). The ISO/IEC 15504 - 3 Information technology - Process assessment Part 3: Guidance of performing an assessment.

ISO/IEC. (2015a). ISO/IEC 33001:2015 Information technology - Process assessment Concepts and terminology.

ISO/IEC. (2015b). ISO/IEC 33002:2015 Information technology - Process assessment Requirements for performing process assessment.

ISO/IEC. (2015c). ISO/IEC 33004:2015 Information technology - Process assessment Requirements for process reference, process assessment and maturity models.

ISO/IEC. (2015d). ISO/IEC 33020:2015 Information technology - Process assessment Process measurement framework for assessment of process capability.

ISO/IEC. (2015e). ISO/IEC TR 33014:2013 Information technology - Process assessment Guide for process improvement.

Kam, C., Senaratna, D., Xiao, Y. and McKinney, B. (2013). The VDC Scorecard: Evaluation of AEC Projects and Industry Trends. CIFE Working Paper \#WP136 (Vol. 136).

Liang, C., Lu, W., Rowlinson, S. and Zhang, X. (2016). Development of a Multifunctional BIM Maturity Model, 142(11). http://doi.org/10.1061/(ASCE)CO.1943-7862.0001186.

Messner, J. I., Anumba, C., Robert Leich, Kreider, R., Nulton, E., Ramesh, A., Weiger, D. and Price, K. (2013). Building Information Modeling Planning Guide for Facility Owners.

National Institute of Building Sciences buildingSMART alliance. (2015). National BIM Standard V3 - Practice Documents. 
Rudd, C. and Sansbury, J. (2013). ITIL ® Maturity Model and Self-assessment Service : user guide, (October), 1-11.

Sarshar, M., Haigh, R. and Amaratunga, R. (2004). Improving project processes: best practice case study. Construction Innovation: Information, Process, Management, 4(2), 69-82. http://doi.org/10.1108/14714170410815015

SCAMPI Upgrade Team. (2011). Standard CMMI Appraisal Method for Process Improvement (SCAMPI) A, Version 1.3: Method Definition Document.

SEI, S. E. I. (2010). CMMI for Development, Version 1.3. Pittsburgh, PA. Retrieved from www.sei.cmu.edu/reports/10tr033.pdf

Succar, B. (2010). Building Information Modelling Maturity Matrix. Handbook of Research on Building Information Modeling and Construction Informatics: Concepts and Technologies. http://doi.org/10.4018/978-1-60566-928-1.ch004

University, I. (2009). BIM Proficiency Matrix. Retrieved from http://www.iu.edu/ vpcpf/consultant-contractor/standards/bim-standards.shtml University of Salford. (2001). SPICE FM.

Waterhouse, R. and Philp, D. (2016). National BIM Report. National BIM Library. 